\title{
POPULATION GENETIC STRUCTURE OF ORTHOTOMICUS EROSUS (WOLLASTON, 1857) (COLEOPTERA: CURCULIONIDAE, SCOLYTINAE) IN PINE FORESTS OF THE MEDITERRANEAN REGION OF TURKEY
}

\author{
SARIKAYA, O. ${ }^{{ }^{*}}-$ ŞEN, I. ${ }^{2 *}$

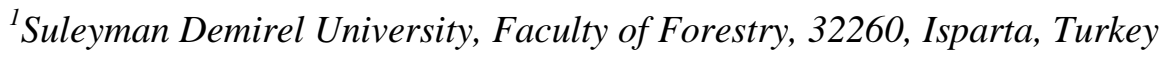 \\ ${ }^{2}$ Suleyman Demirel University, Technology Faculty, 32260, Isparta, Turkey \\ *Corresponding authors \\ e-mail: oguzhansarikaya@sdu.edu.tr; ismailsen32@gmail.com \\ (phone: +90-246-211 39 64; fax: +90-246-2113948) \\ (Received $31^{\text {st }}$ May 2017; accepted $2^{\text {nd }}$ Aug 2017)
}

\begin{abstract}
Orthotomicus erosus (Wollaston, 1857) (Coleoptera: Curculionidae: Scolytinae) is one of the principal pests of Eurasian forests. Gathering data from this study concerning population genetic structure of $O$. erosus would help improving new strategies to control the pest by giving new insights on forest management. The aims of the study were to resolve the population genetic structure of Orthotomicus erosus which distributes Mediterranean Region of Turkey and to determine the factors (such as host pine species and geographic barriers) that contributed to the current distribution of genetic diversity. The beetle samples were collected from 20 stands from the pine forests included in the Mediterranean Region of Turkey. 67 samples were studied using mitochondrial cytochrome oxidase subunit I (COI) gene and Neighbor Joining (NJ) and Maximum Likelihood (ML) analyses were performed. As a result of the study, thirty-seven distinct haplotypes from sixty-seven samples were determined. The species did not form any phylogroup in populations depending on the geographical location according to the NJ and ML analysis. The NJ and ML trees revealed that those $O$. erosus individuals that fed on different pine species did not have genetic variations. Consequently, NJ and ML analysis results reveals that different populations of the species across the Mediterranean Region were not disconnected and isolated geographically either.

Keywords: Orthotomicus erosus, mtDNA, Neighbour Joining, Maximum Likelihood, Turkey
\end{abstract}

\section{Introduction}

Forests have played a very important role for all organisms since the existence of human-beings. However, forestlands have shrunk and have been destroyed due to overutilization and misuse for centuries. Particularly the growing world population in the last century and thus the social pressure as well as the negative impacts such as environmental pollution, forest fire and insect damage have resulted in the shrinkage of forest areas, which still prevails at the same pace (Sarıkaya and Avc1, 2006).

There are several factors that led to shrinkage of forest areas and reduction of their productivity in the Mediterranean Region located in the south of Turkey. Among these factors, harmful insect species play a very important role. Bark beetles are among the most important insect groups that lead to significant economic loss due to the damage they cause in forest trees. The bark beetles that damage the forests in the Mediterranean Region include Mediterranean pine engraver Orthotomicus erosus (Wollaston, 1857), which is highly important because of its damage in pine forests. Although these beetles cause secondary damage, they may cause primary damage just after the dry periods. In this region, especially Pinus brutia is one of most widely distributed species (Karatepe et al., 2014). Orthotomicus erosus (Wollaston) was found in pine (Pinus spp.), fir (Abies 
spp.), spruce (Picea orientalis) and cedar (Cedrus libani) species in Turkey (Schedl, 1961; Tosun, 1975; Selmi, 1989 and 1998; Çanakçığlu and Mol, 1998). Studies conducted in other countries demonstrated that $O$. erosus caused damage in pine species in primarily Mediterranean countries and Middle and South Europe, Iran, Israel, Morocco, Tunisia, Algeria, Crimea, Caucasia, South and North America (Mendel and Halperin, 1982; Mendel, 1983; Pfeffer, 1995; Henin and Pavia, 2004; Lee, 2004; Haack, 2004; Jamaa et al., 2007; Amini et al., 2013; Gómez and Martínez, 2013).

Molecular tests have been increasingly used in systematic and taxonomic studies conducted on insects and contributed to the solution of taxonomic problems thanks to the recent developments, enzymatic amplification of specific regions of a DNA strand In Vitro (PCR), (Mullis et al., 1986), introduction of automatic devices for DNA sequence analysis and superfast computers (Brower and De Salle, 1994; Roderick, 1996; Simon et al., 1994). Current population structure of a species reflects both historic and contemporary ecological and evolutionary forces (Hewitt, 2000). These processes left their signatures in the genomes of species. Thus, current population genetic structure can be used to infer past evolutionary and demographic events within species (Avise, 2000).

There is any study concerning population genetics of O. erosus (Hughes and Vogler 2004) although the species has been included in several molecular studies (Cognato and Felix, 2000; Cognato and Vogler, 2001; Jordal et al., 2008; Cognato, 2013; Jordal and Kambestad, 2014). O. erosus is one of the most damaging bark beetle species to pine forests at the Mediterranean shore latitude in Turkey. Generally a secondary pest, it can immediately gain a primary character especially after the arid periods in the Mediterranean and Aegean regions of Turkey. However, population structure of the species is also unknown in Turkey. Information concerning its population structure could help in the future control of this pest. The aims of the study were to resolve the population genetic structure of O. erosus in the Mediterranean Region of Turkey and to determine the factors (such as host pine species and geographic barriers) that contributed to the current distribution of genetic diversity.

\section{Material and Methods}

In order to collect Orthotomicus erosus samples, sampling plots were selected in the stands where the Brutian pine and black pine grew under different habitat conditions in the Mediterranean Region and the damage caused by the bark beetle was intense and beetle samples were collected from these areas. The adult samples of Orthotomicus erosus were collected from different locations across the Mediterranean Region in 2013. The locations where $O$. erosus samples were collected are presented in Table 1 and Figure 1.

Table 1. Pinus brutia and P. nigra stands where Orthotomicus erosus samples were collected. (Host tree species were symbolised with capital letter N: P. nigra; B: P. brutia in the Abbreviation column)

\begin{tabular}{|c|c|c|c|c|c|}
\hline $\begin{array}{l}\text { Samples } \\
\text { No }\end{array}$ & Abbreviation & Location & Coordinates & Altitude (m) & Host species \\
\hline 1 & B-AntKem & Kemer-Karabucak & $\begin{array}{l}\text { N } 36^{\circ} 58^{\prime} 31^{\prime \prime} \\
\text { E } 30^{\circ} 53^{\prime} 45^{\prime \prime}\end{array}$ & 44 & Pinus brutia \\
\hline 2 & B-AntAks & Akseki-Küser & $\begin{array}{l}\text { N } 37^{\circ} 10^{\prime} 86^{\prime \prime} \\
\text { E } 31^{\circ} 74^{\prime} 35^{\prime \prime}\end{array}$ & 1127 & P. brutia \\
\hline 3 & B-AntKum & Antalya-Kumluca & $\begin{array}{l}\text { N } 36^{\circ} 23^{\prime} 56^{\prime \prime} \\
\text { E } 30^{\circ} 19^{\prime} 22^{\prime \prime}\end{array}$ & 300 & P. brutia \\
\hline
\end{tabular}




$$
\text { - } 917 \text { - }
$$

\begin{tabular}{|c|c|c|c|c|c|}
\hline 4 & N-AntAksCam & Akseki-Çambeleni & $\begin{array}{l}\text { N } 37^{\circ} 14^{\prime} 87^{\prime \prime} \\
\text { E } 31^{\circ} 83^{\prime} 85^{\prime \prime}\end{array}$ & 1367 & P. nigra \\
\hline 5 & N-BurAkc & Burdur-Akçaören & $\begin{array}{l}\text { N } 37^{\circ} 41^{\prime} 64^{\prime \prime} \\
\text { E } 30^{\circ} 19^{\prime} 91^{\prime \prime}\end{array}$ & 1305 & P. nigra \\
\hline 6 & B-BurBuc & Burdur-Bucak Gündoğdu & $\begin{array}{l}\mathrm{N} 37^{\circ} 35^{\prime} 10^{\prime \prime} \\
\mathrm{E} 30^{\circ} 61^{\prime} 66^{\prime \prime}\end{array}$ & 892 & P. brutia \\
\hline 7 & B-IspEgiAsa & Eğirdir-Aşağıgökdere & $\begin{array}{l}\mathrm{N} 37^{\circ} 32^{\prime} 88^{\prime \prime} \\
\text { E } 30^{\circ} 48^{\prime} 45^{\prime \prime}\end{array}$ & 250 & P. brutia \\
\hline 8 & B-MrsTarCam & Tarsus Çamalanı Akarca & $\begin{array}{l}\text { N } 37^{\circ} 31^{\prime} 28^{\prime \prime} \\
\text { E } 34^{\circ} 78^{\prime} 45^{\prime \prime}\end{array}$ & 1200 & P. brutia \\
\hline 9 & B-MerGl & Mersin-Gülnar & $\begin{array}{l}\text { N } 36^{\circ} 32^{\prime} 97^{\prime \prime} \\
\text { E } 33^{\circ} 40^{\prime} 40^{\prime \prime}\end{array}$ & 956 & P. brutia \\
\hline 10 & B-MerAna & Anamur-Demirören village & $\begin{array}{l}\text { N } 36^{\circ} 06^{\prime} 57^{\prime \prime} \\
\text { E } 32^{\circ} 65^{\prime} 62^{\prime \prime}\end{array}$ & 254 & P. brutia \\
\hline 11 & B-MerTar & Mersin-Tarsus & $\begin{array}{l}\text { N } 37^{\circ} 13^{\prime} 04^{\prime \prime} \\
\text { E } 34^{\circ} 54^{\prime} 36^{\prime \prime}\end{array}$ & 950 & P. brutia \\
\hline 12 & B-MrsDav & Mersin-Davultepe & $\begin{array}{l}\text { N } 36^{\circ} 48^{\prime} 49^{\prime \prime} \\
\text { E } 34^{\circ} 22^{\prime} 14^{\prime \prime}\end{array}$ & 760 & P. brutia \\
\hline 13 & N-MerGz & Mersin-Gözne & $\begin{array}{l}\text { N } 37^{\circ} 04^{\prime} 30^{\prime \prime} \\
\text { E } 34^{\circ} 33^{\prime} 30^{\prime \prime}\end{array}$ & 1200 & P. nigra \\
\hline 14 & N-MrsTarCam & Tarsus- Çamalanı, Tekir & $\begin{array}{l}\text { N } 37^{\circ} 31^{\prime} 28^{\prime \prime} \\
\text { E } 34^{\circ} 78^{\prime} 45^{\prime \prime}\end{array}$ & 1325 & P. nigra \\
\hline 15 & B-AdaCuk & $\begin{array}{l}\text { Adana-Çukurova Karahan } \\
\text { Köyü-Tapan Tepe }\end{array}$ & $\begin{array}{l}\text { N } 37^{\circ} 08^{\prime} 18^{\prime \prime} \\
\text { E } 35^{\circ} 17^{\prime} 82^{\prime \prime}\end{array}$ & 141 & P. brutia \\
\hline 16 & B-AdaKad & $\begin{array}{l}\text { Osmaniye-Kadirli- } \\
\text { Börklüler }\end{array}$ & $\begin{array}{l}\text { N } 37^{\circ} 47^{\prime} 17^{\prime \prime} \\
\text { E } 36^{\circ} 20^{\prime} 26^{\prime \prime}\end{array}$ & 627 & P. brutia \\
\hline 17 & B-OsmYar & $\begin{array}{l}\text { Osmaniye-merkez } \\
\text { Yarpuz-Yemşen }\end{array}$ & $\begin{array}{l}\text { N } 37^{\circ} 07^{\prime} 21^{\prime \prime} \\
\text { E } 36^{\circ} 33^{\prime} 94^{\prime \prime}\end{array}$ & 728 & P. brutia \\
\hline 18 & N-AdaKar & Karaisal1-Damlama & $\begin{array}{l}\text { N } 37^{\circ} 35^{\prime} 76^{\prime \prime} \\
\text { E } 34^{\circ} 96^{\prime} 76^{\prime \prime}\end{array}$ & 1271 & P. nigra \\
\hline 19 & B-KmrAnd & Andırın-Efirağızlı & $\begin{array}{l}\text { N } 37^{\circ} 51^{\prime} 78^{\prime \prime} \\
\text { E } 36^{\circ} 37^{\prime} 74^{\prime \prime}\end{array}$ & 625 & P. brutia \\
\hline 20 & N-KmrAndSar & Andırın-Sarıtanışmanlı & $\begin{array}{l}\text { N } 37^{\circ} 67^{\prime} 44^{\prime \prime} \\
\text { E } 36^{\circ} 45^{\prime} 80^{\prime \prime}\end{array}$ & 1436 & P. nigra \\
\hline
\end{tabular}

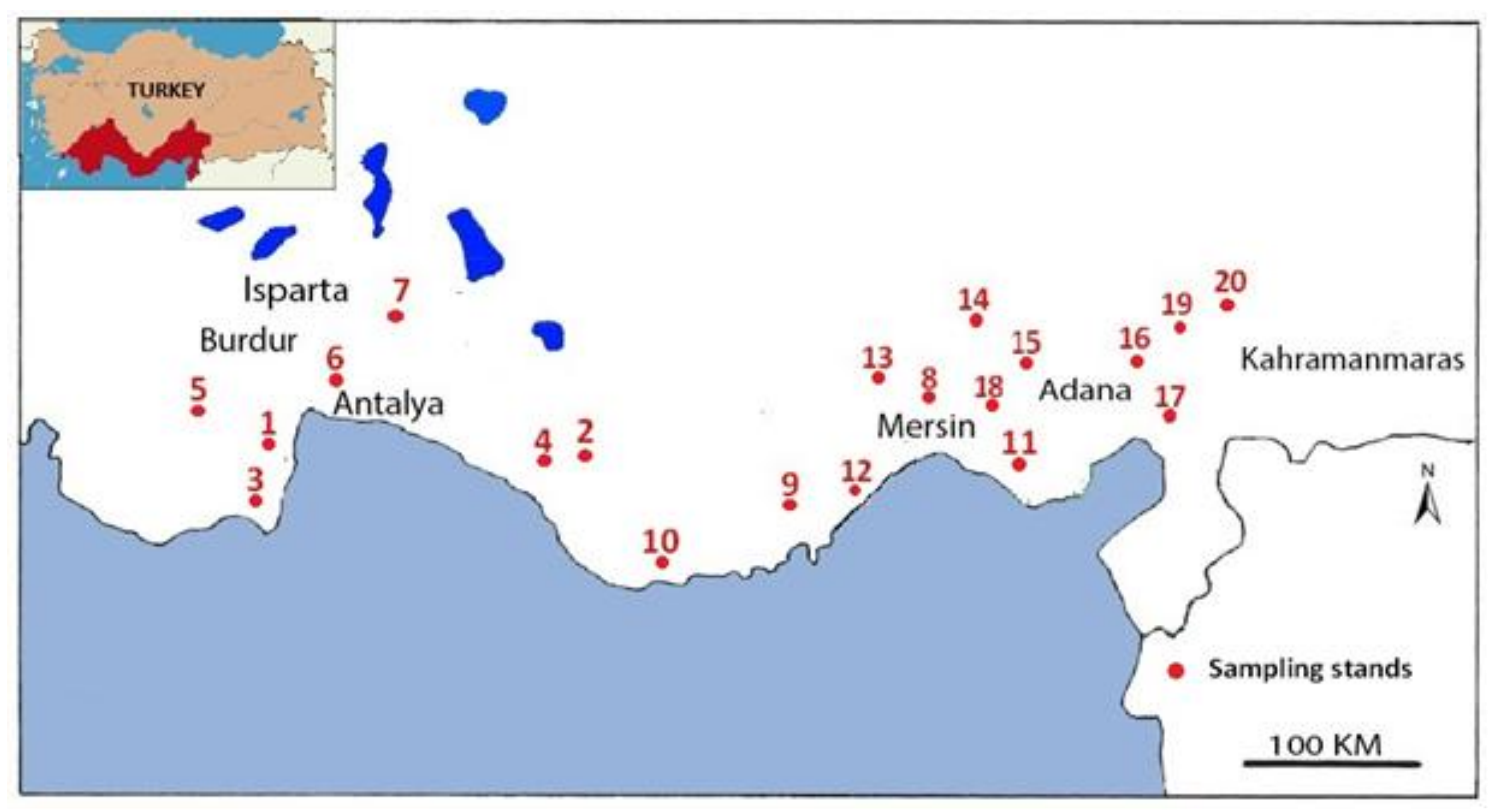

Figure 1. Sampling stands of Orthotomicus erosus specimens 
Trap woods were placed in the sampling plots before the flying period in order to collect the samples. Traps were composed of 12 woods each with a length of $1 \mathrm{~m}$. The samples collected from the trap trees were soaked in pure alcohol of $99 \%$ and stored.

Furthermore, pheromone traps were placed in the sampling plots before flying periods and the samples were collected from these traps. Pheromone preparations containing $1500 \mathrm{mg}$ methyl butanol $+100 \mathrm{mg}$ cis-verbanol $+30 \mathrm{mg}$ Ipsdienol were used in the pheromone traps to capture $O$. erosus. Moreover, samples were collected from trunks maintained in the forest storages and production areas across the region through observation. The collected samples were placed and stored in tubes containing pure alcohol. The tubes where the samples were placed were stored in deep freezer until the performance of genomic DNA (gDNA) isolation.

\section{Genomic DNA isolation}

gDNAs of $O$. erosus samples collected during the field study were isolated from the head and thorax of the beetles. Abdominal and elytra of the samples from which gDNA was isolated were stored at the laboratory for morphological analysis. gDNAs of the samples were isolated with Qiagen DNeasy Blood and Tissue Kit (Qiagen).

\section{Polymerase Chain Reaction (PCR) and DNA sequencing}

The isolated gDNAs were controlled using $0.8 \%$ agarose gel electrophoresis and the gDNA quantity of the samples was diluted to the concentration level that was appropriate for PCR according to their gel appearance. The primers S1718 (5'GGAGGATTTGGAAATTGATTAGTTCC-3') and A2237 (5'CCGAATGCTTCTTTTTTACCT CTTTCTTG-3') were used for the amplification of mitochondrial cytochrome oxidase subunit I (COI) regions of the samples through PCR (Simon et al., 1994; Normark et al. 1999). Thirty cycles of amplification were performed as follows: denaturation step at $94^{\circ} \mathrm{C}$ for 30 seconds, annealing at $48^{\circ} \mathrm{C}$ for 1 min, and extension at $72^{\circ} \mathrm{C}$ for 90 seconds. PCR products were purified with QIAquick PCR purification kit (QIAgen) and sequenced.

\section{Population Genetic Analyses}

The phylogenetic relationships between the haplotypes were analysed and phylogenetic trees were created using Neighbour Joining (NJ) and Maximum Likelihood (ML) algorithms. The best substation model according to the DNA sequencing data was determined using the hierarchical likelihood ratio test (hLRT) and Akaike information criterion (AIC) in MODELTEST v. 3.7 (Posada and Crandall, 1998). The substitution model for the two abovementioned statistics was found to be TIM3+I for upon Orthotomicus erosus by consensus and these criteria were entered as substitution model while constructing the Maximum Likelihood (ML) tree. ML trees were questioned according to the heuristic search approach. The branch support values of ML trees were evaluated through 1000 non-parametric bootstrap analysis (Felsenstein, 1985).

In order to determine the polymorphism and diversity level of Orthotomicus erosus, the number of within populations and among populations average nucleotide differences and nucleotide diversity $(\pi)$ were analysed. In order to determine the significance of the differences between the populations of the species, pairwise Fst values were calculated. 
In order to determine if the populations of the species showed the cases such as enlargement/bottleneck in the past, historical demographic pattern of both species were analysed. To this end, Tajima's D (Tajima, 1989) and Fu's FS (Fu, 1997) neutrality tests were performed for the COI gene regions that were studied. Moreover, sum of squared differences (SSD) and Harpending's Raggedness index (Hri) mismatch distribution analysis were used to check if the sequence data of the species deviated from the possible enlargement model estimation.

\section{Results and Discussion}

67 samples were analysed for Orthotomicus erosus in this study. The DNA sequences of the samples that were studied were aligned, the impractical regions were removed, and a sequence of 488 base pairs that could be used for statistical analysis was obtained. 49 bases out of the sequence of 488 base pairs had mutations. 37 different haplotypes were found in 67 samples that were analysed due to the abovementioned mutations. Some haplotypes were represented more than once.

The within populations and among populations genetic variations of Orthotomicus erosus were analysed through AMOVA (Table 2). The analysis showed that the within populations genetic variation of the species was higher than the among populations variation.

Table 2. Spatial analysis of molecular variance of Orthotomicus erosus. df degrees offreedom

\begin{tabular}{|l|c|c|c|c|}
\hline & d.f. & Sum of squares & Variance components & $\begin{array}{c}\text { Percentage of } \\
\text { variance }\end{array}$ \\
\hline among populations & 18 & 242.876 & $3.11977 \mathrm{Va}$ & 55.07 \\
\hline within populations & 48 & 122.183 & $2.54549 \mathrm{Vb}$ & 44.93 \\
\hline Total & 66 & 365.060 & 5.66525 & \\
\hline
\end{tabular}

The genetic diversity of 67 samples from different populations of Orthotomicus erosus collected from the Mediterranean Region and intraspecific genetic diversity were determined with Neighbour Joining (Figure 2) and Maximum Likelihood (Figure 3) methods. According to the base data obtained prior to the Maximum Likelihood analysis, the substitution model in the COI sequence of the species was found to be TIM3+I in Model test software and the tree was constructed according to that substitution model. To construct both trees, O. erosus, O. proximus and O. suturalis were used as the outgroup. 


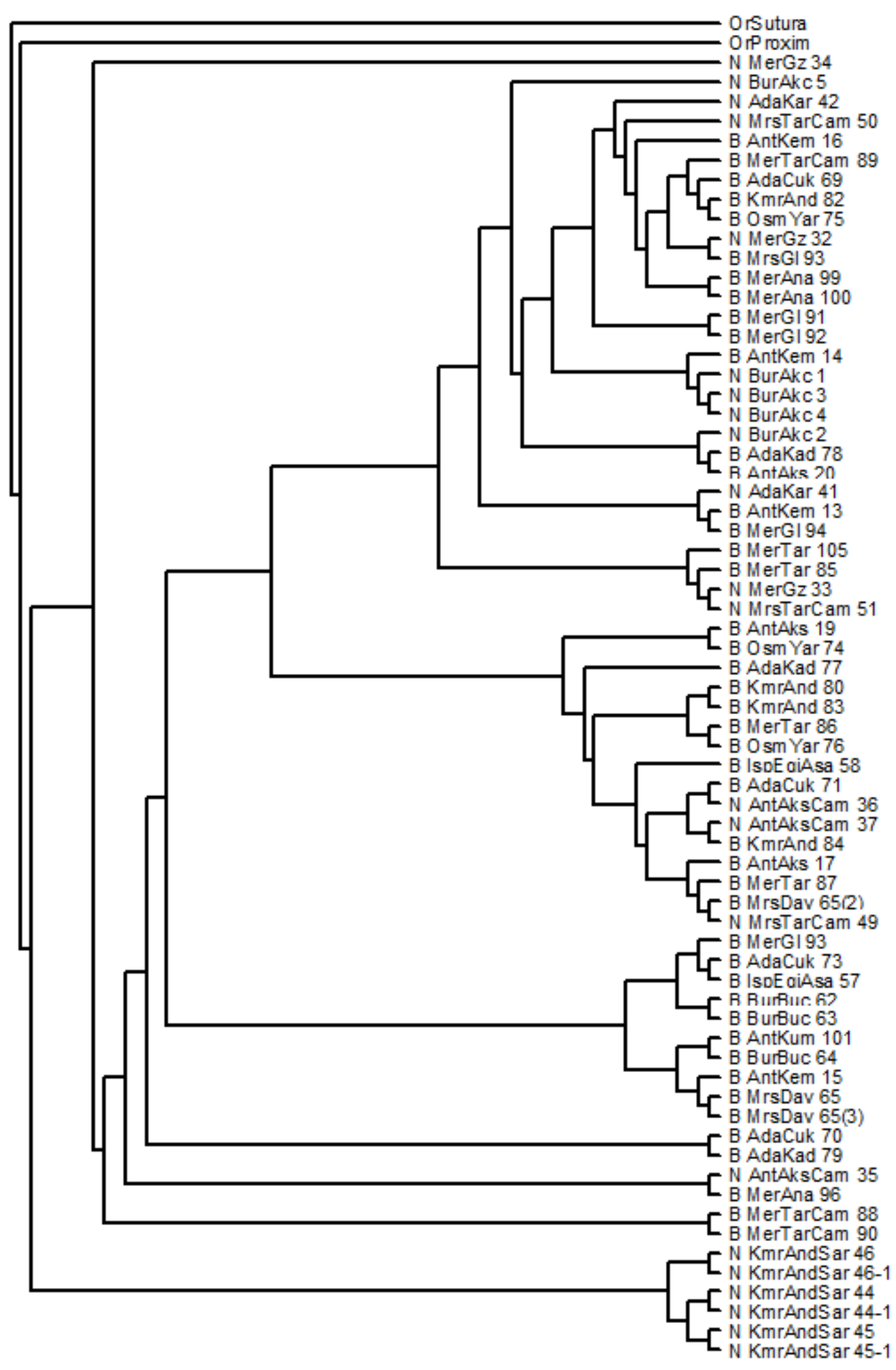

Figure 2. Neighbour Joining tree of $O$. erosus populations 


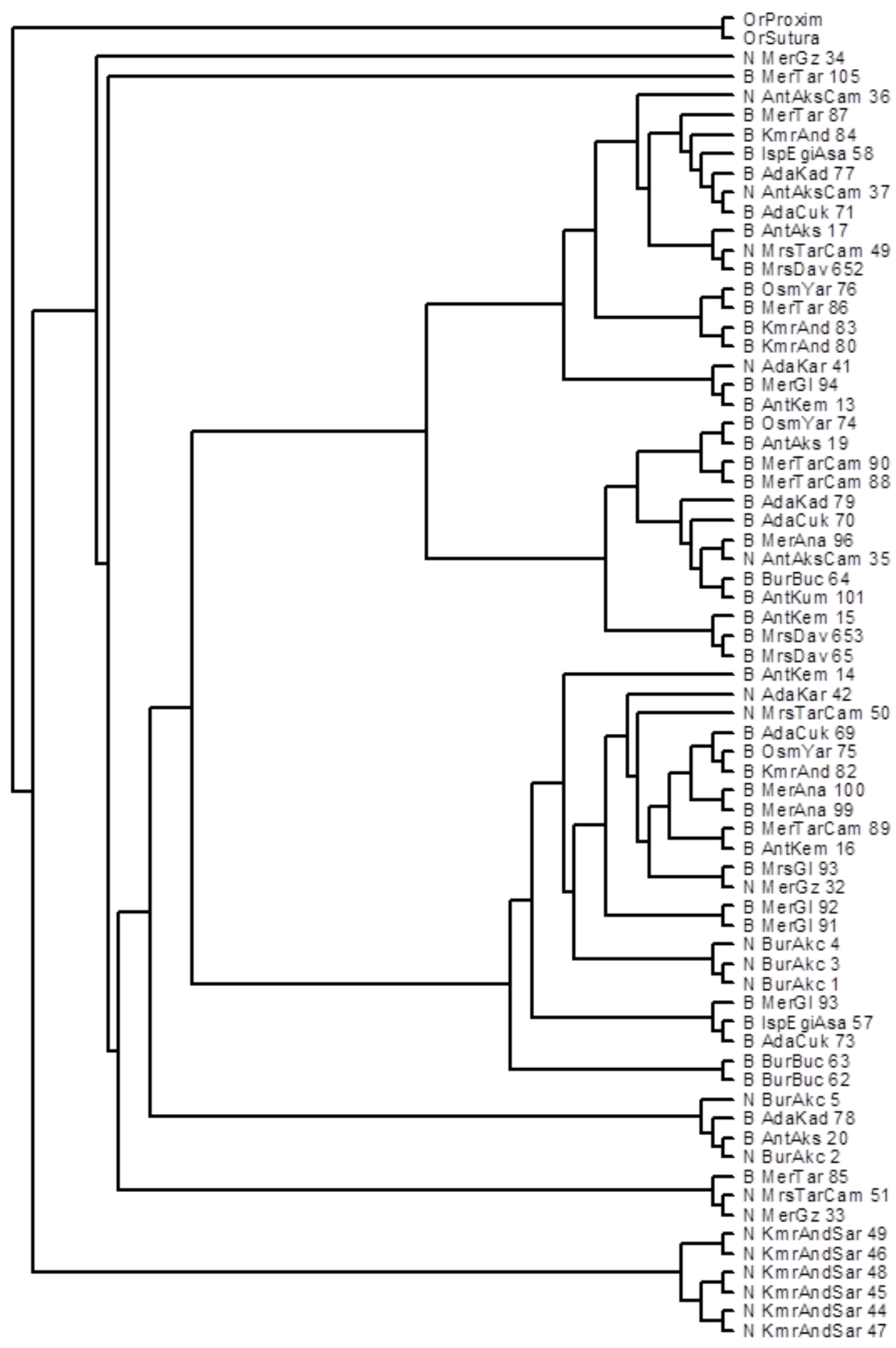

Figure 3. Maximum Likelihood tree of O. erosus populations

The intra-population genetic diversity of different populations of Orthotomicus erosus in the Mediterranean Region and the results of the neutrality test are presented in Table 3. The mismatch distribution analysis of different populations of Orthotomicus erosus in the Mediterranean Region is shown in Table 4; and the FST values of those populations are shown in Table 5. 
Table 3. Genetic diversity of Orthotomicus erosus populations in the Mediterranean Region and the results of the neutrality test; $h$ : haplotype diversity, $\pi$ : nucleotide diversity

\begin{tabular}{|c|c|c|c|c|c|c|c|c|c|c|c|}
\hline & B_AdaCuk & B_AdaKad & N_AdaKar & B_AntAks & $\begin{array}{c}\text { N_AntAksCa } \\
\mathrm{m}\end{array}$ & B_AntKem_Kum & N_BurAkc & B_BurBuc & $\begin{array}{c}\text { B_IspEg } \\
\text { iAsa }\end{array}$ & B_KmrAnd & N_KmrAndSar \\
\hline Individual number & 4 & 3 & 2 & 3 & 3 & 5 & 5 & 3 & 2 & 4 & 6 \\
\hline $3 h 3$ & $\begin{array}{c}1.0000+/- \\
0.1768\end{array}$ & $\begin{array}{c}1.0000+/- \\
0.2722\end{array}$ & $\begin{array}{c}1.0000+/- \\
0.5000\end{array}$ & $\begin{array}{c}1.0000+/- \\
0.2722\end{array}$ & $\begin{array}{c}1.0000+/- \\
0.2722\end{array}$ & $1.0000+/-0.1265$ & $\begin{array}{c}1.0000+/- \\
0.1265\end{array}$ & $\begin{array}{c}1.0000+/- \\
0.2722\end{array}$ & $\begin{array}{c}1.0000 \\
+/- \\
0.5000\end{array}$ & $\begin{array}{c}1.0000+/- \\
0.1768\end{array}$ & $\begin{array}{c}1.0000+/- \\
0.0962\end{array}$ \\
\hline$\pi$ & $\begin{array}{c}0.016052+/- \\
0.011315\end{array}$ & $\begin{array}{c}0.013661+/- \\
0.011061\end{array}$ & $\begin{array}{c}0.016393 \\
+/- \\
0.017388\end{array}$ & $\begin{array}{c}0.010929+/- \\
0.009016\end{array}$ & $\begin{array}{c}0.002732+/- \\
0.002807\end{array}$ & $\begin{array}{c}0.013525+/- \\
0.008996\end{array}$ & $\begin{array}{c}0.002049+/- \\
0.001908\end{array}$ & $\begin{array}{c}0.008197+/- \\
0.006966\end{array}$ & $\begin{array}{c}0.01024 \\
6+/- \\
0.01122 \\
4\end{array}$ & $\begin{array}{c}0.012295 \\
+/- \\
0.008853\end{array}$ & $\begin{array}{c}0.005464+/- \\
0.003896\end{array}$ \\
\hline Theta $(S)$ & 8.18182 & 6.66667 & 8.00000 & 5.33333 & 1.33333 & 7.20000 & 0.96000 & 4.00000 & 5.00000 & 6.54545 & 2.18978 \\
\hline Theta $(S)$ s.d. & 4.74042 & 4.32784 & 6.0000 & 3.52767 & 1.09834 & 3.92508 & 0.75803 & 2.72554 & 3.87298 & 3.85876 & 1.34160 \\
\hline Theta $(\pi)$ & 7.83333 & 6.66667 & 8.00000 & 5.33333 & 1.33333 & 6.60000 & 1.00000 & 4.00000 & 5.00000 & 6.00000 & 2.66667 \\
\hline Theta $(\pi)$ s.d. & 5.52152 & 5.39776 & 8.48528 & 4.39978 & 1.36987 & 4.38999 & 0.93095 & 3.39935 & 5.47723 & 4.32049 & 1.90127 \\
\hline Tajima's D & -0.43306 & 0.00000 & 0.00000 & 0.00000 & 0.00000 & -0.60926 & 0.24314 & 0.00000 & 0.00000 & -0.84046 & 121.883 \\
\hline Tajima's D p-value & 0.48700 & 0.70900 & 100.000 & 0.75600 & 0.94000 & 0.36800 & 0.76000 & 0.77100 & 100.000 & 0.09800 & 0.89200 \\
\hline FS & 0.04321 & 0.70320 & 207.944 & 0.45758 & -121.640 & -0.91837 & -477.912 & 0.13353 & 160.944 & -0.28768 & -357.660 \\
\hline FS p-value & 0.28900 & 0.44400 & 0.53600 & 0.38100 & 0.06600 & 0.15800 & 0.00000 & 0.28300 & 0.50100 & 0.23600 & 0.00400 \\
\hline & B_MerAna & N_MerGz & B_MerGl & B_MerTar & B_MerTarCam & B_MrsDav & N_MerTarTek & B_OsmYar & Mean & s.d. & \\
\hline Individual number & 3 & 3 & 5 & 4 & 3 & 3 & 3 & 3 & & & \\
\hline$h$ & $\begin{array}{c}1.0000+/- \\
0.2722\end{array}$ & $\begin{array}{c}1.0000+/- \\
0.2722\end{array}$ & $\begin{array}{c}1.0000+/- \\
0.1265\end{array}$ & $\begin{array}{c}1.0000+/- \\
0.1768\end{array}$ & $\begin{array}{c}1.0000+/- \\
0.2722\end{array}$ & $1.0000+/-0.2722$ & $\begin{array}{c}1.0000+/- \\
0.2722\end{array}$ & $\begin{array}{c}1.0000+/- \\
0.2722\end{array}$ & & & \\
\hline$\pi$ & $\begin{array}{c}0.016393+/- \\
0.013103\end{array}$ & $\begin{array}{c}0.012295+/- \\
0.010039\end{array}$ & $\begin{array}{c}0.010656 \\
+/- \\
0.007249\end{array}$ & $\begin{array}{c}0.005464+/- \\
0.004352\end{array}$ & $\begin{array}{c}0.015027+/- \\
0.012082\end{array}$ & $\begin{array}{c}0.009563+/- \\
0.007992\end{array}$ & $\begin{array}{c}0.016393+/- \\
0.013103\end{array}$ & $\begin{array}{c}0.015027+/- \\
0.012082\end{array}$ & & & \\
\hline
\end{tabular}




\begin{tabular}{|c|c|c|c|c|c|c|c|c|c|c|}
\hline Theta $(S)$ & 8.00000 & 6.00000 & 5.76000 & 2.72727 & 7.33333 & 4.66667 & 8.00000 & 7.33333 & 5.53847 & 2.33498 \\
\hline Theta $(S)$ s.d. & 5.12696 & 3.92792 & 3.20568 & 1.78962 & 4.72749 & 3.12694 & 5.12696 & 4.72749 & 3.57554 & 1.47199 \\
\hline Theta $(\pi)$ & 8.00000 & 6.00000 & 5.20000 & 2.66667 & 7.33333 & 4.66667 & 8.00000 & 7.33333 & 5.45439 & 2.24756 \\
\hline Theta $(\pi)$ s.d. & 6.39444 & 4.89898 & 3.53761 & 2.12374 & 5.89622 & 3.89998 & 6.39444 & 5.89622 & 4.45448 & 1.93464 \\
\hline Tajima's D & 0.00000 & 0.00000 & -0.70314 & -0.21249 & 0.00000 & 0.00000 & 0.00000 & 0.00000 & -0.07034 & 0.42527 \\
\hline Tajima's D p-value & 0.70000 & 0.72500 & 0.32700 & 0.59100 & 0.71100 & 0.76200 & 0.70200 & 0.69600 & 0.68395 & 0.23034 \\
\hline FS & 0.90079 & 0.58779 & -128.257 & -141.422 & 0.80681 & 0.30830 & 0.90079 & 0.80681 & -0.21775 & 169.616 \\
\hline FS p-value & 0.44400 & 0.39300 & 0.10600 & 0.06300 & 0.44200 & 0.37000 & 0.44600 & 0.39600 & 0.29253 & 0.17609 \\
\hline
\end{tabular}

Table 4. Mismatch distribution analysis of Orthotomicus erosus

\begin{tabular}{|c|c|c|c|c|c|c|c|c|c|c|c|}
\hline & B_AdaCuk & B_AdaKad & N_AdaKar & B_AntAks & N_AntAksCam & B_AntKem_Kum & N_BurAkc & B_BurBuc & B_IspEgiAsa & B_KmrAnd & N_KmrAndSar \\
\hline$S S D$ & 0.15942 & 0.20122 & 0.00000 & 0.22311 & 0.26508 & 0.04733 & 0.00764 & 0.36418 & 0.00000 & 0.17790 & 0.09176 \\
\hline$S S D$ p-value & 0.26000 & 0.26000 & 0.00000 & 0.45000 & 0.14000 & 0.74000 & 0.83000 & 0.13000 & 0.00000 & 0.15000 & 0.15000 \\
\hline Hri & 0.16667 & 0.66667 & 0.00000 & 0.66667 & 100.000 & 0.12000 & 0.11000 & 111.111 & 0.00000 & 0.33333 & 0.32444 \\
\hline Hri p-value & 0.73000 & 0.54000 & 0.00000 & 0.56000 & 0.54000 & 0.68000 & 0.88000 & 0.27000 & 0.00000 & 0.64000 & 0.17000 \\
\hline
\end{tabular}

\begin{tabular}{|c|c|c|c|c|c|c|c|c|c|c|}
\hline & B_MerAna & N_MerGz & B_MerGl & B_MerTar & B_MerTarCam & B_MrsDav & N_MerTarTek & B_OsmYar & Mean & s.d. \\
\hline$S S D$ & 0.44599 & 0.36835 & 0.07231 & 0.29711 & 0.44161 & 0.13406 & 0.14034 & 0.21895 & 0.19244 & 0.14260 \\
\hline$S S D$ p-value & 0.02000 & 0.10000 & 0.39000 & 0.02000 & 0.01000 & 0.46000 & 0.41000 & 0.27000 & 0.25211 & 0.24310 \\
\hline Hri & 100.000 & 111.111 & 0.20000 & 111.111 & 100.000 & 0.44444 & 0.22222 & 0.66667 & 0.53971 & 0.41232 \\
\hline Hri p-value & 0.49000 & 0.36000 & 0.34000 & 0.02000 & 0.54000 & 0.83000 & 0.91000 & 0.60000 & 0.47895 & 0.28614 \\
\hline
\end{tabular}


Table 5. Pairwise Fst values of Orthotomicus erosus populations

\begin{tabular}{|c|c|c|c|c|c|c|c|c|c|c|c|c|c|c|c|c|c|c|c|c|c|c|}
\hline & 1 & 2 & 3 & 4 & 5 & & 6 & 7 & $\varepsilon$ & & & & 10 & 11 & 12 & 13 & 14 & 15 & 16 & 17 & 18 & 19 \\
\hline 1 & 0,000 & & & & & & & & & & & & & & & & & & & & & \\
\hline 2 & $-0,056$ & 0,000 & & & & & & & & & & & & & & & & & & & & \\
\hline 3 & $-0,214$ & $-0,136$ & 0,000 & & & & & & & & & & & & & & & & & & & \\
\hline 4 & $-0,072$ & $-0,080$ & $-0,063$ & 0,000 & & & & & & & & & & & & & & & & & & \\
\hline 5 & $-0,031$ & 0,000 & 0,172 & 0,000 & 0,00 & & & & & & & & & & & & & & & & & \\
\hline 6 & 0,074 & 0,128 & $-0,007$ & 0,089 & 0,18 & & 0,000 & & & & & & & & & & & & & & & \\
\hline 7 & 0,138 & 0,271 & 0,286 & 0,152 & 0,54 & & 0,228 & 0,000 & & & & & & & & & & & & & & \\
\hline 8 & 0,114 & 0,186 & 0,213 & 0,208 & 0,27 & & 0,161 & 0,545 & $\overline{0,0}$ & & & & & & & & & & & & & \\
\hline 9 & $-0,094$ & $-0,031$ & $-0,083$ & $-0,076$ & 0,13 & & 0,115 & 0,441 & 0,2 & & & & & & & & & & & & & \\
\hline 10 & $-0,085$ & 0,031 & $-0,072$ & $-0,068$ & 0,06 & & 0,134 & 0,211 & 0,2 & & & & 0,000 & & & & & & & & & \\
\hline 11 & 0,875 & 0,895 & 0,901 & 0,903 & 0,93 & & 0,878 & 0,944 & 0,9 & & & & 0,895 & 0,000 & & & & & & & & \\
\hline 12 & 0,129 & 0,305 & 0,040 & 0,221 & 0,42 & & 0,249 & 0,483 & 0,4 & & & & 0,190 & 0,880 & 0,000 & & & & & & & \\
\hline 13 & $-0,038$ & 0,123 & $-0,017$ & 0,105 & 0,23 & & 0,093 & 0,326 & 0,2 & & & & 0,122 & 0,892 & 0,100 & 0,000 & & & & & & \\
\hline 14 & 0,001 & 0,155 & $-0,137$ & 0,073 & 0,24 & & 0,127 & 0,099 & 0,3 & & & & 0,115 & 0,894 & 0,166 & 0,035 & 0,000 & & & & & \\
\hline 15 & 0,000 & 0,045 & 0,158 & $-0,009$ & 0,04 & & 0,177 & 0,348 & 0,3 & & & & 0,037 & 0,924 & 0,366 & 0,077 & 0,210 & 0,000 & & & & \\
\hline 16 & 0,059 & 0,171 & 0,010 & 0,136 & 0,30 & & 0,198 & 0,357 & 0,3 & & & & 0,193 & 0,884 & 0,127 & 0,032 & 0,149 & 0,295 & 0,000 & & & \\
\hline 17 & 0,093 & 0,105 & 0,152 & 0,118 & 0,18 & & 0,213 & 0,503 & 0,2 & & & & 0,168 & 0,910 & 0,406 & 0,200 & 0,281 & 0,181 & 0,325 & 0,000 & & \\
\hline 18 & $-0,066$ & 0,000 & $-0,091$ & 0,016 & 0,06 & & 0,095 & 0,348 & 0,1 & & & & 0,014 & 0,884 & 0,143 & $-0,125$ & 0,100 & 0,020 & 0,138 & 0,081 & 0,000 & \\
\hline 19 & $-0,185$ & $-0,068$ & $-0,267$ & $-0,213$ & 0,00 & & 0,032 & 0,160 & $\overline{0,1}$ & & & & $-0,167$ & 0,890 & 0,068 & 0,000 & $-0,041$ & $-0,063$ & 0,015 & 0,069 & $-0,078$ & 0,000 \\
\hline & 1 & B-AdaCuk & 6 & \multicolumn{2}{|c|}{ B-AntKem-Kum } & 11 & & \multicolumn{2}{|l|}{ N-KmrAndSar } & & & \multicolumn{3}{|c|}{$\frac{1}{\mathrm{~B}-\text { MerTarCam }}$} & & & & & & & & \\
\hline & 2 & B-AdaKad & 7 & \multicolumn{2}{|l|}{ N-BurAkc } & 12 & & B-MerAna & & & & \multicolumn{3}{|c|}{ B-MrsDav } & & & & & & & & \\
\hline & 3 & N-AdaKar & 8 & \multicolumn{2}{|l|}{ B-BurBuc } & 13 & & N-MerGz & & & & \multicolumn{3}{|c|}{ N-MerTarTek } & & & & & & & & \\
\hline & 4 & B-AntAks & 9 & \multicolumn{2}{|l|}{ B-IspEgiAsa } & 14 & & B-MerGl & & & & \multicolumn{3}{|c|}{ B-OsmYar } & & & & & & & & \\
\hline & 5 & N-AntAksCam & 10 & \multicolumn{2}{|l|}{ B-KmrAnd } & 15 & & B-MerTar & & \multicolumn{2}{|c|}{20} & & & & & & & & & & & \\
\hline
\end{tabular}


The intraspecific diversity of Orthotomicus erosus was determined by using COI gene sequence that had 488 base pairs. The species did not form any phylogroup in populations depending on the geographical location according to the NJ and ML analysis. The genetic variations of $O$. erosus populations in Pinus brutia and P. nigra were also analysed. The NJ and ML trees revealed that those $O$. erosus individuals that fed on different pine species did not have genetic variations. Moreover, NJ and ML trees also showed that different populations of the species across the Mediterranean Region were not disconnected and isolated geographically either.

The number of the haplotypes shared by the populations of $O$. erosus was low. AMOVA results also revealed that the variations within and among populations were very similar. This indicates that the intraspecific genetic diversity was very high.

High genetic diversity of genetic lineages were also reported for other animal species from Turkey (Gündüz et al., 2005; Stone et al., 2007; Bardakçı et al., 2006, Mutun, 2011). High haplotype diversity might be due to the continuous introduction of individuals from different locations.

The highest nucleotide diversity was found in the populations distributed in Pinus brutia trees in Adana-Çukurova Karahan Village, Mersin-Anamur-Demirören Village and Mersin-Tarsus and in P. nigra trees in Adana Karaisal1-Damlama district, MersinTarsus-Çamalanı, Tekir and Mersin-Gözne.

According to the FST values of $O$. erosus; there was a gene flow between the populations in Adana-Çukurova Karahan village and Adana-Kadirli Börklüler, AntalyaAkseki-Küser district, Akseki-Çambeleni, Adana Karaisalı-Damlama; Isparta, EğirdirAşağıgökdere, Kahramanmaraş Andırın-Efirağızlı, Mersin-Gözne, Mersin-TarsusÇamalanı- Tekir and Osmaniye- Yarpuz-Yemşen; populations in Adana-Kadirli Börklüler and Adana Karaisal1-Damlama district; populations in Antalya-AksekiÇambeleni, Isparta, Eğirdir-Aşağıgökdere, Osmaniye-Yarpuz-Yemşen; populations in Adana Karaisal1-Damlama and Antalya-Akseki-Küser district, Antalya Kemer and Kumluca, Isparta, Eğirdir-Aşağıgökdere, Kahramanmaraş Andırın-Efirağızlı, MersinGözne, Mersin-Gülnar, Mersin-Tarsus- Çamalanı, Tekir and Osmaniye-YarpuzYemşen; populations in Antalya-Akseki-Küser and Isparta, Eğirdir-Aşağıgökdere, Kahramanmaraş Andırın-Efirağızlı and Mersin-Tarsus; populations in Mersin-Tarsus Çamalanı-Tekir and Isparta, Eğirdir-Aşağıgökdere and Mersin-Gözne, populations in Osmaniye-Yarpuz-Yemşen and Isparta, Eğirdir-Aşağıgökdere, Kahramanmaraş Andırın-Efirağızlı, Mersin-Gülnar and Mersin-Tarsus. The topologies of NJ and ML trees and negative FST values indicated that $O$. erosus could be distributed in quite long distances.

D and FS test results of $O$. erosus showed that the populations in Antalya- Kemer and Antalya-Kumluca, Kahramanmaraş-Andırın Efirağızlı, Mersin-Gülnar and MersinTarsus had an enlargement in the past. Furthermore, the sum of squared differences (SSD) and Raggedness index (Hri) results revealed that the populations only in AntalyaKemer, Antalya-Kumluca and Mersin-Gülnar had enlargement.

\section{Conclusion}

Knowing of the genetic variations of bark beetles at local and regional level will provide highly useful data for forest management. The findings of this study, in which the genetic variations of Orthotomicus erosus that damaged pine trees including primarily the Brutian pine in the Mediterranean Region were analysed, show that there 
were not significant within population genetic variations or differences. These findings indicate that the concerned harmful bark beetles are highly mobile.

It was found that individuals of $O$. erosus that can feed on different pine species in the Mediterranean Region did not have any genetic variations and different populations were not disconnected and isolated geographically. This indicates that change of host does not result in dependence on a specific host for $O$. erosus; therefore, there is no barrier before the distribution of this species.

$O$. erosus does not have any sub-species. On the other hand, there is a need for further studies to explore if $O$. erosus depends on a specific geographical location and specific host species across Turkey considering its wide distribution in the country.

Acknowledgements. This study was a part of TUBITAK-1002 project. We express our sincere appreciation to The Scientific and Technological Research Council of Turkey (TUBITAK) for their financial support by project which numbered as 1130198 .

\section{REFERENCES}

[1] Amini, S., Hosseini, R., Sohani, M.M. (2013): A faunal study of bark beetles (Coleoptera: Curculionidae: Scolytinae) in Guilan province in North of Iran. -Entomofauna 34: 169176.

[2] Avise, J. C. (2000): Phylogeography: the History and Formation of Species. - Harvard University Press: Cambridge, MA, USA.

[3] Bardakci, F., Degerli, N., Ozdemir, O., Basibuyuk, H.H. (2006): Phylogeography of the Turkish brown trout Salmo trutta L.: mitochondrial DNA PCR-RFLP variation. - Journal of Fish Biology 68: 36-55.

[4] Brower, A. V. Z, DeSalle, R. (1994): Practical and theoretical considerations for choice of a DNA sequence region in insect molecular systematics, with a short review of published studies using nuclear gene regions. - Annals of the Entomological Society of America 87: 702-716.

[5] Cognato, A.I., Felix, A. H. (2000): Sperling Phylogeny of Ips DeGeer Species (Coleoptera: Scolytidae) Inferred from Mitochondrial Cytochrome Oxidase I DNA Sequence. -Molecular Phylogenetics and Evolution 14 (3): 445-460.

[6] Cognato, A.I., Vogler, A. (2001): Exploring Data Interaction and Nucleotide Alignment in a Multiple Gene Analysis of Ips (Coleoptera: Scolytinae). -Syst. Biol. 50(6): 758-780.

[7] Cognato, A.I. (2013): Molecular phylogeny and taxonomic review of Premnobiini Browne, 1962 (Coleoptera: Curculionidae: Scolytinae). -Front. Ecol. Evol. 1(1): 1-12.

[8] Çanakçıŏlu, H., Mol, T. (1998): Orman Entomolojisi, Zararlı ve Yararlı Böcekler.İstanbul Üniversitesi Orman Fakültesi Yayınları, İstanbul.

[9] Felsenstein, J. (1985): Confidence Limits on Phylogenies: An Approach Using the Bootstrap. -Evolution 39: 783-791.

[10] Fu, Y.X. (1997): Statistical tests of neutrality of mutations against population growth, hitchhiking and background selection. Genetics 147 (2): 915-925.

[11] Gómez, D., Martínez, G. (2013): Bark Beetles in Pine Tree Plantations in Uruguay: First Record of Orthotomicus erosus Wollaston (Coleoptera: Curculionidae: Scolytinae). - The Coleopterists Bulletin 67(4):470-472.

[12] Gunduz, I., Rambau, R.V., Tez, C., Searle, J.B. (2005): Mitochondrial DNA variation in the western house mouse (Mus musculus domesticus) close to its site of origin: studies in Turkey. -Biological Journal of The Linnean Society 84: 3.

[13] Haack, R.A. (2004): Orthotomicus erosus: A new Pine-Infesting Bark Beetle in the United States. -Newsletter of Michigan Entomological Society 49: 3-4. 
[14] Henin, J.M., Pavia, M.R. (2004): Interactions between Orthotomicus erosus (Woll.) (Col., Scolytidae) and the Argentine ant Linepithema humile (Mayr) (Hym.,Formicidae). Journal of Pest Science 77: 113-117.

[15] Hewitt, G. (2000): The genetic legacy of the Quanternary ice ages. -Nature 405: 907-913.

[16] Hughes, J., Vogler, A.P. (2004): The phylogeny of acorn weevils (genus Curculio) from mitochondrial and nuclear DNA sequences: the problem of incomplete data. - Molecular Phylogenetics and Evolution 32: 601-615.

[17] Jamaa, M.L.B., Lieutier, F., Yart, A., Jerraya, A., Khouja, M.L. (2007): The virulence of phytopathogenic fungi associated with the bark beetles Tomicus piniperda and Orthotomicus erosus in Tunisia. -Forest Pathology 37: 51-63.

[18] Jordal, B., Gillespie, J.J., Cognato, A.I. (2008): Secondary structure alignment and direct optimization of $28 \mathrm{~S}$ rDNA sequences provide limited phylogenetic resolution in bark and ambrosia beetles (Curculionidae: Scolytinae). -Zoologica Scripta 37 (1): 43-56.

[19] Jordal, B.H., Kambestad, M. (2014): DNA barcoding of bark and ambrosia beetles reveals excessive NUMTs and consistent east-west divergence across Palearctic forests. Molecular Ecology Resources 14: 7-17.

[20] Karatepe, Y., Özçelik, R., Gürlevik, N., Yavuz, H., Kırış, R. (2014): Batı Akdeniz'de farklı yetişme ortamı bölgelerindeki kızılçam (Pinus brutia Ten.) ormanlarının vejetasyon yapısının ekolojik değerlendirilmesi. -SDU Faculty of Forestry Journal 15: 1-8

[21] Lee, J.C., Smith, S.L., Seybold, S.J. (2004): Mediterranean Pine Engraver. Pest Alert. USDA Forest Service, State and Private Forestry Pacific Southwest Region, R5-PR-016.

[22] Mendel, Z. (1983): Seasonal history of Orthotomicus erosus (Coleoptera:Scolytidae) in Israel. -Phytoparasitica 11: 13-24.

[23] Mendel, Z., Halperin, J. (1982): The biology and behaviour of Orthotomicus erosus in Israel. -Phytoparasitica 10: 169-181.

[24] Mullis, K, Faloona, F., Scharf, S., Saiki, R., Horn, G., Erlich, H. (1986): Specific enzymatic amplification of DNA in-vitro: the polymerase chain reaction. Cold Spring Harbor Symp. - Quantitative Biology 51: 263-274.

[25] Mutun, S. (2011): Intraspecific genetic diversity and phylogeography of the oak gall wasp Andricus lucidus (Hymenoptera: Cynipidae) populations in Anatolia. -Turkish Journal of Zoology 35: 559-570.

[26] Normark, B.B., Jordal, B.H. and Farrell, B.D. (1999): Origin of a haplodiploid beetle lineage. - Proc R Soc Lond B 266: 2253-2259.

[27] Pfeffer, A. (1995): Zentral und westpaläarktische Borken und Kernkäfer. Naturhistorisches Museum Basel.

[28] Roderick, GK. (1996): Geographic structure of insect populations: gene flow, phylogeography, and their uses. - Annual Review of Entomology 41: 325-352.

[29] Posada D, Crandall K.A. (1998): "Modeltest: testing the model of DNA substitution". Bioinformatics 14: 817-818.

[30] Sarıkaya, O., Avcı, M. (2006): Kabuk Böceklerine Karşı Ormanlarımızda Alınabilecek Koruyucu Önlemler. -Orman Mühendisliği Dergisi 43: 26-31.

[31] Schedl, K.E. (1961): Borkenkäfer aus der Türkei, II. Mitteilung 190. Beitrag zur Morphologie and Systematik der Scolytoidea. 34: 184-188.

[32] Selmi, E. (1989): Türkiye Ipinae (Coleoptera, Scolytidae) Türleri. İ.Ü. - Orman Fakültesi, İstanbul.

[33] Selmi, E. (1998): Türkiye Kabuk Böcekleri ve Savaş1, İ.Ü. Yayın No: 4042, Fen Bilimleri Enstitüsü Yayın No : 11, İstanbul.

[34] Simon, C., Frati, F., Beckenbach, A., Crespi, B., Liu, H., Flok, P. (1994): Evolution, weighting, and phylogenetic utility of mitochondrial gene sequences and a compilation of conserved polymerase chain reaction primers. - Annals of the Entomological Society of America 87: 651-701.

[35] Stone, G.N., Challis, R.J., Atkinson, R.J., Csöka, G., Hayward, A., Melika, G., Mutun, S., Preuss, S., Rokas, A., Sadeghi, E. (2007): The phylogeographical clade trade: tracing the 
impact of humanmediated dispersal on the colonization of northern Europe by the oak gall wasp Andricus kollari. -Molecular Ecology 16: 2768-2781.

[36] Tajima, F. (1989): Statistical method for testing the neutral mutation hypothesis by DNA polymorphism. - Genetics 123: 585-595.

[37] Tosun, İ. (1975): Akdeniz Bölgesi, İğne Yapraklı Ormanlarda Zarar Yapan Böcekler ve Önemli Türlerin Parazit ve Yırtıcıları Üzerine Araştırmalar.- Journal of the Faculty of Forestry, Istanbul University 26(A):2, http://dergipark.ulakbim.gov.tr/jffiu/article/view/5000094148 